\title{
AYURLOG
}

National Journal of Research in Ayurved Science

A peer-reviewed open access Indexed e-journal of Ayurved

http://www.ayurlog.com

April- 2020 | Volume 08 ${ }^{\text {th }} \mid$ Issue: $2^{\text {nd }}$

ISSN: 2320-7329

\section{Hemorrhoids - patho-physiology and classification - an analytical approach with special reference to Arshas}

\section{Thacker Dipesh $\mathbf{S}^{* 1}$, Turlapati Srinivas ${ }^{2}$,}

1. Post Graduation Scholar,

2. Guide And HOD,

Department of Shalya Tantra, Yashvant Ayurved College \& Research Center,

Kodoli, Kplhapur, Maharashtra

*Corresponding Author: dr.dipesh14@gmail.com, 9429298871

\section{Abstract:}

Hemorrhoids are extremely common problem. Its prevalence rate is highest among all Anorectal disorders. Hemorrhoids are actually a symptomatic anal cushion. ${ }^{(1)}$ Newer concepts of the Pathophysiology of hemorrhoids have been defined during the past 30 to 40 years, yet it hasn't updated at under graduate and post graduate education level. ${ }^{(2)}$

Most common Modern classification, used in prospect to treatment is according to its degree of prolapse, i.e. grade I to IV. Many times in regards to practice, this conventional classification doesn't provide sufficient details about the exact extent of the disease. So there was a need of making classification more precise. All the acharyas of Ayurved has mentioned about Arsh. A brief review of that also will included in this article.
In this review article we have tried to show some focus regarding Anal Cushion theory for Pathophysiology of hemorrhoids. Attempt has been also made to review the newer guidelines for Hemorrhoids classification.

This article is intended for the use of all the practitioners and academicians and students.

Keyword: Anal Cushions, Sub Grades of Piles, Pathophysiology, Types, ACRSI Guidelines 2016, Arsh, Novel Classification

Introduction: Hemorrhoids are era old problem known to mankind. Nearly half of the population generally experience one haemorrhoidal episode at some point during their lives. Even WHO has declared 20th November of each year as "World Piles Day" (3), which clearly indicates the 
infiltration of this disease all over the world. It also causes tremendous physical and mental sufferings to mankind. This shows the seriousness of disease and hence proper attention regarding its origin and classification is indeed needed. In this review article an effort has been made to emphasize on that.

Concept of Anal Cushion: It was thought, that hemorrhoids are varicose veins, but it's not true. Every one does not have hemorrhoids. But everybody has anal cushions. The anal cushions are consist of mainly 3 structures, viz (A) Blood vessels (B) Smooth muscle (Treitz's muscle), and (C) Elastic connective tissue in the sub mucosa (Fig. 1).

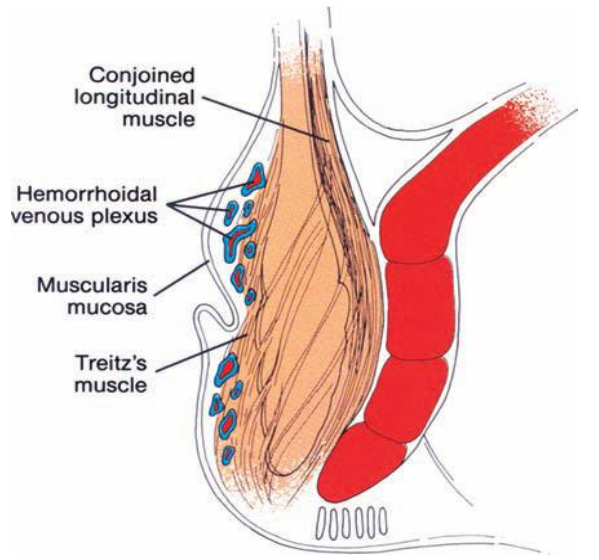

Anal Cushions are normal anatomical structure. Its presence is found in children, fetus and even in the embryo ${ }^{(4)}$

\section{Location of Anal Cushion:}

- Primary Anal Cushion- They is 3 in number, located in the upper anal canal, between anorectal ring (puborectalis muscle) and dentate line.
- Their sites are constant: left lateral, right anterolateral, and right posterolateral.

- Secondary Anal Cushion- may be present between the main cushions

\section{Figure 2}

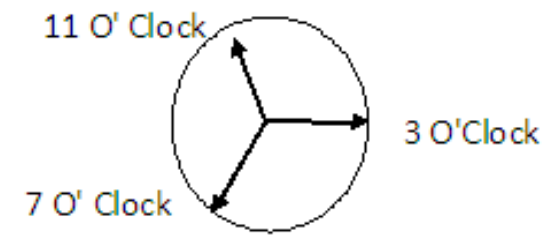

Anal Cushion Theory: Main movement of musculus submucosae ani (Treitz's muscle) and its richly intermingled elastic fibers is anchoring and flattening. When it is disrupted, result in prolapse. So sliding downward of the anal cushions is the correct etiologic theory of Hemorrhoids. Secondary manifestations are Hypertrophy and congestion of the vascular tissue.

Hemorrhoids are associated with straining, and an irregular bowel habit. These both features are compatible with above theory. Tenesmus from diarrhea, and Hard, bulky stools, cause straining. That cause engorgement of the cushions, which lead to pushing out of cushions while defecation. Submucosal Treitz's muscle may disrupt also due to repeated stretching and results in prolapse of cushion. ${ }^{(5)}$.

Classification: Among all described classifications, the most useful classification in practice currently is 
conventional one, based upon its degree of prolapse, described by grades of hemorrhoids from I to IV. ${ }^{(6)}$ But this also many times doesn't give sufficient details about exact extent of disease; hence it was needed to make it more specific.
Based upon above problems, The Association of Colon \& Rectal Surgeons of India (ACRSI) has published a new guideline in 2016. In which new classification was proposed as below. ${ }^{(7)}$

\section{Table 1}

Table 1- New Proposed Classifiaction of Hemmorhhoid s according to ACRSI

\begin{tabular}{|l|l|}
\hline Grade & Characteristics \\
\hline I & Remaining inside the anal canal \\
\hline II & Protrude during defecation and reduce spontaneously \\
\hline III & Need further manual reposition \\
\hline IV & Piles that remain prolapsed outside and external haemorrhoids \\
\hline $\begin{array}{l}\text { Each of the } \\
\text { number of piles, and presence of circumferential piles or thrombosis, by the suffix as below }\end{array}$ \\
\hline a & Single pile mass \\
\hline b & Two piles but <50\% circumference \\
\hline c & Circumferential piles occupying more than half circumference of the anal canal \\
\hline d & Thrombosed or gangrenous piles (complicated) \\
\hline
\end{tabular}

Classification according to Ayurved:

Description of Arsh has been found in all the samhitas of Ayurveda. various classification of Arsh is available in ayurved treatises. It is based on its, origin, Involved Dosha, Symptomes and treatment. all type of Arsh are summerised in a table below.

Table 2 : Classification of Arsha according to Samhita

\begin{tabular}{|l|l|l|l|}
\hline Sr. No & Samhita & $\begin{array}{l}\text { No. of } \\
\text { Types }\end{array}$ & Name of Types \\
\hline 1 & Charak Samhita & 2 & (1) Sushk (2) Aardra \\
\cline { 3 - 5 } & & 2 & (1) Sahaj (2) Janmotar Kalaj \\
\hline 2 & Sushrut Shamhita & 2 & (1) Bahya (2) Abhayantar \\
\hline
\end{tabular}




\begin{tabular}{|c|c|c|c|}
\hline & & 3 & (1) Sadhya (2) Yapya (3) Ashadhya \\
\hline & & 4 & $\begin{array}{l}\text { (1) Bheshaj Sadhya (2)Kshar Sadhya } \\
\text { (3) AgniKarmaSadhya (4)Shastra Sadhya }\end{array}$ \\
\hline & & 6 & $\begin{array}{l}\text { (1) Vataj } \quad \text { (2) Pittaj } \\
\text { (4) Raktaj (5)Sannipataj } \quad \text { (6) Sahaj }\end{array}$ \\
\hline 3 & Ashtanga & 2 & (1) Sushk (2) Aardra \\
\hline & Hmadya & 6 & $\begin{array}{l}\text { (1) Vataj (2) Pittaj } \\
\text { (4) Raktaj (5)Sannipataj } \\
\text { (6) Sahaj }\end{array}$ \\
\hline 4 & Ashtang Sangrah & 2 & (1) Sushk (2) Aardra \\
\hline & & 6 & $\begin{array}{l}\text { (1) Vataj (2) Pittaj } \\
\text { (4) Raktaj (5)Sannipataj Kaphaj }\end{array}$ \\
\hline 5 & Madhav Nidan & 6 & $\begin{array}{ccc}\text { (1) Vataj } & \text { (2) Pittaj } & \text { (3) Kaphaj } \\
\text { (4) Raktaj } & \text { (5)Sannipataj } & \text { (6) Sahaj }\end{array}$ \\
\hline 6 & Sarangdhar Shamhita & 2 & (1) Sushk (2) Aardra \\
\hline & & 2 & (2) Janmotar Kalaj \\
\hline & & 6 & $\begin{array}{rcr}\text { (1) Vataj } & \text { (2) Pittaj } & \text { (3) Kaphaj } \\
\text { (4) Raktaj } & \text { (5)Sannipataj } & \text { (6) Sahaj }\end{array}$ \\
\hline
\end{tabular}

Discussion: According to most popular Varicose Vein theory, it was assumed that, due to pathological changes, veins of internal rectal venous plexus dilates, but it proved invalid, as in fact, these dilatations are normal. When anal varices occur as the result of portal hypertension (a rare event), the appearance is quite different from that of hemorrhoids.

Thomson did histological study of Haemarrhoidectomy specimens. And found no sign of vascular hyperplasia. Also specimens were similar to cadaver specimens in which there was no evidence of hemorrhoids. Hence the vascular hyperplasia theory is also obsolete.

According to Haas and Bernstein, specimens from patients with hemorrhoids, showed, disintegrated and fragmented anchoring and supporting connective tissue above the anal cushions. This also supports Anal Cushion Theory. ${ }^{(8)}$

Word Arsh, is a very broad terminology. All Hemorrhoids are Arsh but all Arsh are not Hemmorhoids.

Conclusion: From all above discussion, it is clear that hemorrhoid is a mechanical disease. Main pathological factor for 
hemorrhoid is straining due to any cause, which results in, prolapse of anal cushion. This prolapsed anal cushion state is called hemorrhoid. Hence Hemorrhoids are symptomatic anal cushions and doesn't require any management if it is asymptomatic.

For the ease of better description, communication and management of hemorrhoids, newer proposed classification may prove very useful.

Hence above both novel concepts should be included in the syllabus of all the academics as well as practice as soon as possible.

\section{References:}

1. Bailey \& Love's SHORT PRACTICE of SURGERY, 25 $5^{\text {th }}$ edition2008, published by Edward Arnold (Publishers) Ltd, p 1253

2. Dr. Philip Gordon, Principles and Practice of Surgery for the Colon, Rectum, and Anus Third Edition,
2007, published by Informa Healthcare USA, p 144

3. Ajai Kumar, A Classical Review On Arsha (Haemorrhoids/Piles): Current Treatment Strategies And Future Prospects, IJAPR, August 2016, Volume 4, Issue 8 p1

4. Dr. Philip Gordon, Principles and Practice of Surgery for the Colon, Rectum, and Anus Third Edition, 2007, published by Informa Healthcare USA, p 144

5. Dr. Philip Gordon, Principles and Practice of Surgery for the Colon, Rectum, and Anus Third Edition, 2007, published by Informa Healthcare USA,, p 145

6. Dr. Amandeep Kaur, CAUSES AND TREATMENT OF PILES (ARSH) A REVIEW, wjpmr, 2018,4(6), 133-135

7. Niranjan Agarwal, Indian J Surg (February 2017) 79(1):58-61

8. Dr. Philip Gordon, Principles and Practice of Surgery for the Colon, Rectum, and Anus Third Edition, 2007, published by Informa Healthcare USA,, p 145

\section{Cite this article:}

"Hemorrhoids - patho-physiology and classification - an analytical approach w. s. r. to Arshas."

Thacker Dipesh S, Turlapati Srinivas 